\title{
Laboreal
}

Volume $17 \mathrm{~N}^{\circ} 1$ | 2021

Trabalhar hoje: mudanças, permanências, estratégias, reinvenções

\section{O trabalho doméstico não remunerado de mães na pandemia da COVID-19 : mudanças e permanências}

El trabajo doméstico no remunerado de las madres en la pandemia de COVID-19: cambios y permanencias

Le travail domestique non rémunéré des mères dans la pandémie de COVID-19: changements et séjours

The unpaid domestic work of mothers in the COVID-19 pandemic : changes and permanencies

Lívia Borges Hoffmann Dorna

\section{OpenEdition}

\section{Journals}

\section{Edição electrónica}

URL: https://journals.openedition.org/laboreal/17860

DOI: $10.4000 /$ laboreal. 17860

ISSN: 1646-5237

\section{Editora}

Universidade do Porto

\section{Refêrencia eletrónica}

Lívia Borges Hoffmann Dorna, «O trabalho doméstico não remunerado de mães na pandemia da COVID-19 : mudanças e permanências», Laboreal [Online], Volume $17 N^{0} 1$ | 2021, posto online no dia 18 junho 2021, consultado o 20 junho 2021. URL: http://journals.openedition.org/laboreal/17860 ; DOI: https://doi.org/10.4000/laboreal.17860

Este documento foi criado de forma automática no dia 20 junho 2021

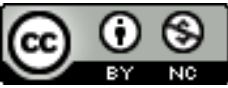

Laboreal está licenciado com uma Licença Creative Commons - Atribuição-NãoComercial 4.0 Internacional. 


\section{O trabalho doméstico não remunerado de mães na pandemia da COVID-19 : mudanças e permanências}

El trabajo doméstico no remunerado de las madres en la pandemia de COVID-19: cambios y permanencias

Le travail domestique non rémunéré des mères dans la pandémie de COVID-19: changements et séjours

The unpaid domestic work of mothers in the COVID-19 pandemic : changes and permanencies

Lívia Borges Hoffmann Dorna

\section{NOTA DO EDITOR}

Manuscrito recebido em : 13/11/2020

Aceite após peritagem em : 06/04/2021

\section{Introdução : os custos da pandemia sob o recorte de gênero}

1 Desde o início da pandemia do novo coronavírus, por todo o mundo, estudiosos das mais diversas áreas se dedicaram a mensurar e estimar os seus custos - econômicos, sociais, emocionais. Muitos demonstraram que, embora se trate de uma enfermidade epidêmica amplamente disseminada entre grande parte dos países e que tenha atingido diferentes classes, raças, gêneros e idades, a pandemia não afetou a todos da mesma forma - os seus custos são marcados por diversas desigualdades sociais. Entre elas, a 
desigualdade de gênero : as pandemias têm, assim, impactos e implicações diferentes para mulheres e homens.

2 Estudos anteriores sobre os impactos do vírus zika no Brasil (Human Rights Watch, 2017) e do ébola na África (Menéndez, Lucas, Munguambe, \& Langer, 2015) demonstraram como as mulheres podem ser desproporcionalmente afetadas por emergências de saúde pública quando comparadas aos homens. Cabe ressaltar que nem todas as mulheres são igualmente afetadas, uma vez que, para além do gênero, existem outros marcadores sociais da diferença, como raça, classe econômica e região de moradia, que explicam por quais motivos determinados grupos estão mais expostos nestes contextos (Brito et al., 2020).

3 No início da pandemia da COVID-19, a Organização das Nações Unidas (ONU Mulheres, 2020) emitiu um alerta mundial dirigido a autoridades políticas, sanitárias e organizações sociais, no qual enfatizava os impactos das emergências de saúde pública sob o viés de gênero. Dentre os impactos econômicos, o documento ressaltava que as quarentenas afetam setores altamente geradores de empregos para as mulheres, como comércio e turismo. As mulheres também são as que ocupam em maior proporção o mercado de trabalho informal, o que faz com que a redução da atividade econômica afete, em primeira instância, estas trabalhadoras. Além disso, as mulheres representam no mundo cerca de $70 \%$ dos trabalhadores do setor da saúde e social (World Health Organization, 2019) e são, portanto, a maioria na linha de frente da resposta à pandemia como profissionais da saúde e voluntárias nas comunidades - e, por isso, além de assumirem mais custos físicos e emocionais, expõem-se mais ao risco de infeção.

4 O contexto de pandemia também impacta os indicadores de violência contra mulheres e meninas, especialmente a violência doméstica, em função do aumento das tensões em casa, da diminuição da autonomia financeira feminina e da maior dificuldade em acessar serviços essenciais de proteção. Em diversos países, autoridades governamentais, ativistas dos direitos das mulheres e parcerias da sociedade civil alertaram, já no início do confinamento, para as crescentes denúncias de violência doméstica e o aumento da demanda para abrigo de emergência para mulheres e meninas [1].

5 Outra implicação direta desse contexto para as mulheres refere-se ao trabalho de cuidado não remunerado e à sua distribuição desigual entre os gêneros. Anterior à pandemia, esta desigualdade tende a se agravar em tempos de crise, já que, em função da saturação dos sistemas de saúde e do fechamento das escolas, as tarefas adicionais de cuidado recaem principalmente sobre elas que, em geral, são as responsáveis por cuidar de familiares doentes, pessoas idosas e crianças. Em 2019, período anterior à pandemia, em comparação aos homens, as mulheres brasileiras já dedicavam quase o dobro de horas às tarefas de cuidado da casa e de outras pessoas (Instituto Brasileiro de Geografia e Estatística, 2019). A pesquisa 'Sem Parar : o trabalho e a vida das mulheres na pandemia' ouviu 2.641 mulheres nos meses de abril e maio de 2020 e constatou que mais da metade das entrevistadas passou a cuidar de alguém durante a crise, incluindo a assistência a familiares, amigos e vizinhos (Sempreviva Organização Feminista \& Gênero e Número, 2020).

6 O objetivo deste artigo é compreender as implicações da COVID-19 para este trabalho doméstico não remunerado de cuidados da casa e dos filhos, ressaltando as mudanças e permanências nos arranjos familiares, a partir de investigação realizada por meio de 
pesquisa on-line com 360 mães brasileiras que têm filhos de até 12 anos. Antes de apresentarmos os resultados da investigação, fazem-se necessárias algumas breves conceituações.

\section{0 trabalho doméstico de cuidado da casa e das crianças : alguns conceitos}

7 Nas sociedades capitalistas, o conceito mais evocado para designar trabalho é aquele estabelecido a partir da Revolução Industrial, que o limita ao assalariamento - o tempo trocado por remuneração. Limitar o conceito de trabalho a esta definição tem por efeito, no entanto, encobrir outras definições possíveis de trabalho, excluindo, por exemplo, as atividades relativas ao cuidado da casa e das crianças.

8 Sob o impulso do movimento feminista da década de 1960 - que possibilitou a tomada de consciência de uma enorme massa de trabalho realizada gratuitamente pelas mulheres no contexto da família - e a partir da iniciativa de Danièle Kergoat, o Grupo de Estudos sobre a Divisão Social e Sexual do Trabalho [2] propôs uma desconstrução/ reconstrução do conceito de trabalho, abrangendo também trabalho não assalariado, não remunerado, não mercantil e informal. Para esta perspectiva, trabalho profissional e trabalho doméstico, produção e reprodução, assalariamento e família, classe social e sexo social são categorias indissociáveis (Kergoat, 2009).

9 Na mesma direção, a Ergologia vai apontar a necessidade de alargar o conceito de trabalho, acreditando que este exercício nos obriga a não tomar o trabalho no sentido stricto sensu, mercantil, como o único trabalho digno de atenção. Aprofundar a abordagem do trabalho 'em geral' permite mensurar as continuidades, as circulações e as transferências, em todos os sentidos, entre o trabalho informal, o doméstico e as formas mercantis de contrato (Schwartz, 2007a).

10 Embora o trabalho doméstico de cuidado da casa e das pessoas diga respeito a toda a sociedade, historicamente ele vem sendo atribuído, quase exclusivamente, às mulheres. O modo de produção capitalista construiu-se sobre a separação dos lugares e tempos da produção e da reprodução: aos homens coube o trabalho produtivo, extralar, assalariado; às mulheres, o trabalho reprodutivo, aquele realizado no domínio doméstico e que abrange as tarefas relativas à reprodução da força de trabalho (Hirata \& Kergoat, 2007).

11 O trabalho doméstico envolve um conjunto de atividades : aquelas necessárias para que os trabalhadores assalariados possam descansar e renovar suas forças para o trabalho produtivo do dia seguinte - tais como as tarefas de limpeza e arrumação da casa, lavagem das roupas e preparo dos alimentos; e também as atividades relacionadas à formação de uma nova geração de trabalhadores para a sociedade - tais como a gravidez, o parto, os cuidados e a socialização das crianças (Bruschini \& Rosemberg, 1982). Nesse sentido, a esfera da reprodução é lugar também da produção, uma vez que este trabalho das mulheres em casa produz vidas e valores fundamentais para a sociedade. Trata-se de um trabalho que pressupõe uma relação de serviço entre pessoas e exige disponibilidade permanente do tempo das mulheres (Fougeyrollas-Schwebel, 2009). Como ressalta Federici (2019) :

“embora isso não resulte em um salário para nós mesmas, produzimos o produto mais precioso que existe no mercado capitalista: a força de 
trabalho. O trabalho doméstico é muito mais do que limpar a casa. É servir aos assalariados física, emocional e sexualmente, preparando-os para o trabalho dia após dia. É cuidar das nossas crianças - os trabalhadores do futuro -, amparando-as desde o nascimento e ao longo da vida escolar, garantindo que o seu desempenho esteja de acordo com o que é esperado pelo capitalismo. Isso significa que, por trás de toda fábrica, de toda escola, de todo escritório, de toda mina, há o trabalho oculto de milhões de mulheres" (p. 68).

12 Mesmo que seja imprescindível para a manutenção e reprodução da sociedade e do capital, este trabalho tem sido muito pouco valorizado e permanece, em grande parte, invisibilizado. Muitas autoras feministas já demonstraram como tal invisibilidade tem sido produzida a partir de discursos que caracterizam a esfera do privado como o 'verdadeiro universo da mulher'. Discursos que, repetidos ao longo do processo de socialização, designam lugares específicos para os homens e para as mulheres na divisão social e sexual do trabalho. Desde muito cedo, o processo de socialização constrói, assim, papéis sociais e 'qualidades masculinas e femininas' coerentes com as atribuições de cada um.

Trata-se, portanto, de um trabalho que não apenas é imposto às mulheres desde a mais tenra infância, mas também é transformado em atributo natural da psique e da personalidade femininas. Desta forma, é atribuída às mulheres uma série de características que as tornariam mais aptas para o trabalho de cuidado e que, em contrapartida, permitiriam aos homens escaparem, legitimamente, destas tarefas. Não obstante, uma abordagem combinada da Psicodinâmica do Trabalho e da Sociologia das Relações de Sexo nos permite desnaturalizar as modalidades de subjetividade classicamente consideradas como pertencentes à constelação psíquica feminina, situando seu surgimento não na natureza da mulher e sim no trabalho de cuidado (Molinier, 2004a).

Segundo Hirata e Kergoat (2007), a divisão social do trabalho produtivo e reprodutivo é modulada histórica e socialmente e tem dois princípios organizadores : o princípio de separação, segundo o qual existem trabalhos de homens e trabalhos de mulheres; e o princípio de hierarquização - um trabalho de homem 'vale' mais do que um trabalho de mulher. Se estes dois princípios organizadores podem ser encontrados em todas as sociedades conhecidas, isto não significa, no entanto, que a divisão do trabalho entre os sexos seja um dado imutável. Ao contrário, ela tem uma incrível plasticidade - suas modalidades concretas variam grandemente no tempo e no espaço. "O que é estável não são as situações (que evoluem sempre), e sim a distância entre os grupos de sexo" (Hirata \& Kergoat, 2007, p. 600). É nesse sentido que as autoras sinalizam para um paradoxo : tudo muda, mas nada muda - para elas, a continuidade das relações sociais de sexo parece garantir a estabilidade da divisão sexual do trabalho para além das mudanças conjunturais.

Nas últimas décadas, as mulheres começaram a ocupar cada vez mais espaço no mercado de trabalho formal, remunerado. Para Sorj e Fontes (2012), a crescente participação feminina no mercado de trabalho assalariado alterou o padrão de família, antes constituído por um provedor masculino e uma cuidadora feminina: no novo modelo, a tendência predominante é que os homens invistam seu tempo prioritariamente no mercado de trabalho, enquanto as mulheres se dividem entre trabalho remunerado e cuidados da casa e da família. 
Hirata e Kergoat (2007) utilizam quatro modelos para descrever os papéis assumidos por homens e mulheres nas esferas doméstica e profissional, no contexto da sociedade francesa :

- no 'modelo tradicional', o papel na família e o papel doméstico são assumidos inteiramente pelas mulheres, enquanto o papel de 'provedor' é atribuído aos homens ;

- no 'modelo de conciliação', cabe quase exclusivamente às mulheres 'conciliar' vida familiar e vida profissional. Na França, o termo 'conciliação' vem sendo alvo de críticas por alguns pesquisadores, que propõem a sua substituição por 'conflito', 'tensão' ou 'contradição', de forma a evidenciar a natureza fundamentalmente conflituosa da incumbência simultânea às mulheres de responsabilidades profissionais e familiares;

- no modelo do 'paradigma da parceria' presume-se a igualdade de estatutos sociais entre os sexos, considerando mulheres e homens como parceiros e as relações entre eles mais em termos de igualdade do que de poder. Ainda que possa, no plano individual, alimentar uma prática de divisão das tarefas domésticas no casal, as pesquisas de emprego do tempo realizadas na França mostram que a realidade das práticas sociais não confirma a atualidade desse modelo ;

- 'modelo da delegação', segundo as autoras, se deve à polarização do emprego das mulheres na França e ao crescimento da categoria de profissões de nível superior e de executivas : as mulheres das sociedades do Norte investem cada vez mais em suas carreiras e, para isso, precisam externalizar 'seu' trabalho doméstico às mulheres em situação precária, sejam francesas ou imigrantes.

17 Os modelos de divisão sexual do trabalho descritos por Hirata e Kergoat (2007) são bastante úteis para a compreensão da relação entre trabalho profissional e doméstico também no Brasil, ainda que se tenha aqui algumas especificidades. Assim como na França, as mulheres brasileiras seguem dedicando consistentemente mais horas do que os homens ao trabalho doméstico. Segundo o IBGE (2019), em 2019, os homens dedicaram em média 11 horas semanais aos afazeres domésticos ou ao cuidado de pessoas, enquanto as mulheres dedicaram quase o dobro : 21,4 horas ou $95 \%$ a mais do que eles. Esta diferença entre as médias masculina e feminina é maior do que a constatada em 2016: aumentou de 9,9 para 10,4 horas semanais em 2019.

Sob a rubrica afazeres domésticos, esconde-se um considerável volume de atividades que mantêm ocupadas mulheres de todas as camadas sociais. Entre elas, são as esposas e, principalmente, as mães as que dedicam número mais elevado de horas semanais a estas tarefas ; e, dentre as que têm filhos, são as mães de crianças pequenas aquelas cujo tempo semanal de dedicação ao trabalho doméstico é o mais elevado (Bruschini, 2006). Nos lares brasileiros de maior renda, onde frequentemente se conta com o trabalho de empregadas domésticas e/ou babás, há uma redução no número de horas dedicadas pelas mulheres a esses afazeres. Ainda assim, essas mulheres despendem mais horas com o trabalho doméstico do que os homens, porque seguem responsáveis pela gestão das tarefas delegadas. Apenas recentemente o IBGE começou a considerar também o planejamento deste trabalho na lista de afazeres domésticos.

o que se observa, dessa forma, é que a revolução da mulher na área profissional não vem sendo acompanhada de transformações no plano social mais amplo. Mesmo em meio a tantas reconfigurações ocorridas ao longo do último século sob a perspectiva de gênero - incluindo aí o movimento feminista da década de 1960 -, "poucas mulheres, qualquer que seja a sua condição social, escapam do trabalho doméstico" (FougeyrollasSchwebel, 2009, p. 260). Para Hirata e Kergoat (2007) : 
“o que é mais espantoso é a maneira como as mulheres, mesmo plenamente conscientes da opressão, da desigualdade da divisão do trabalho doméstico, continuam a se incumbir do essencial desse trabalho doméstico, inclusive entre as militantes feministas, sindicalistas, políticas, plenamente conscientes dessa desigualdade" (p. 607).

\section{A pandemia da COVID-19 e o trabalho doméstico : quando tudo muda, o que muda?} dos governantes, em consonância com a recomendação da Organização Mundial da Saúde, foi o isolamento social, ou seja, a restrição à circulação como forma de conter a propagação do vírus, extremamente contagioso. A orientação 'fique em casa', no entanto, acabou por reeditar para algumas famílias a dinâmica pré-capitalista em que trabalho e vida em geral não estavam separados no tempo e no espaço, mas lhe deu contornos atuais, dentre os quais as tecnologias de informação e comunicação (TICs) têm papel fundamental.

Muitas organizações instituíram o teletrabalho - aquele realizado fora das instalações do empregador e mediado pelas TICs -, visto que este se apresentou como uma das possibilidades de dar continuidade a certas atividades. Até a pandemia, a adoção destas práticas de trabalho remoto se apresentava mais lenta do que o previsto, variando substancialmente entre $2 \%$ e $40 \%$ dos empregados, a depender do país, da ocupação, do setor e da frequência com que os empregados se envolvem neste tipo de trabalho, conforme aponta o estudo realizado em 15 países (Eurofound \& International Labour Office, 2017).

Apesar do crescente interesse dos pesquisadores, o estudo ressalta que a compreensão e a comparação da incidência de teletrabalho esbarram em desafios conceituais, uma vez que os termos usados para descrever esse fenômeno e as definições operacionais nas fontes de dados variam entre os países - alguns, por exemplo, referem-se mais amplamente a todas as pessoas que trabalham em casa, incluindo os trabalhadores informais. É o caso do levantamento realizado pelo IBGE (2018), que registrou, em 2018, o maior contingente de brasileiros trabalhando no domicílio desde que teve início a série histórica da pesquisa, como resultado da alta informalidade no país. Na ocasião, eram 3,8 milhões de trabalhadores, o que correspondia a 5,2 \% da população ocupada.

A Pesquisa Nacional por Amostra de Domicílios COVID-19 (IBGE, 2020) registrou, durante o mês de maio de 2020, 8,7 milhões de trabalhadores exercendo, ainda que parcialmente, trabalho remoto, o equivalente a $13,3 \%$ das pessoas ocupadas no país. Deste total, o Sudeste correspondeu a $59 \%$, sendo a região com a maior quantidade de trabalhadores atuando de forma remota ; 72,8 \% possuíam Ensino Superior completo ; $63,7 \%$ eram brancos e $34,3 \%$ eram pardos ou pretos; os homens correspondiam a $46,4 \%$ do total, enquanto as mulheres, a 53,6 \%. O levantamento demonstra que, mesmo em um contexto de pandemia, o trabalho remoto no Brasil não é uma realidade para grande parte dos trabalhadores do país, mantendo-se abaixo das estimativas do Instituto de Pesquisa Econômica Aplicada (Ipea) (2020), que apontou que $22,7 \%$ das ocupações teriam potencial para este arranjo de trabalho.

Laboreal, Volume $17 \mathrm{~N}^{\circ} 1$ | 2021 

para a adoção do trabalho remoto, ele também se apresenta como um dos seus principais desafios, uma vez que tem sido verificada a tendência à extensão das jornadas de trabalho e à sobreposição entre o trabalho remunerado e a vida pessoal (interferência trabalho-casa) (Eurofound \& ILO, 2017). Para aqueles a quem a pandemia impôs uma transição brusca para o trabalho remoto, o desafio de gerir concomitantemente vida profissional e pessoal parece ter sido dificultado em função do isolamento social, especialmente nos domicílios com crianças. Em grande parte destes lares, a família deixou de contar com o suporte das instituições escolares e passou a permanecer mais horas em casa, aumentando o volume das tarefas domésticas; em alguns casos, prescindiu também da ajuda de outros familiares e do trabalho de empregadas domésticas e/ou babás.

Assim, em muitos domicílios, a rotina de cuidados da casa e da família não apenas foi estendida em algumas horas, mas também passou a incluir atividades que antes ficavam a cargo de outras pessoas ou instituições. O trabalho doméstico, que já vinha, em grande parte, sendo desconsiderado pelas sociedades mercantis, parece ter sido esquecido, mais uma vez, nesses arranjos temporários (ou seriam definitivos?) de trabalho remoto durante a pandemia.

\section{A pesquisa}

\subsection{0 método utilizado}

Interessados em compreender de que maneira a pandemia do novo coronavírus impactou o trabalho doméstico de cuidados da casa e dos familiares, em especial das mulheres que têm filhos pequenos, realizamos um levantamento, a partir de questionário on-line, com mães de um ou mais filhos(as) com idade(s) igual(is) ou inferior a 12 anos. 0 questionário foi proposto pela autora do artigo em resposta à chamada para uma iniciativa colaborativa intitulada 'Laboratório de Emergência CoVID-19', convocada pela Silo - Arte e Latitude Rural [3]. Desenvolvido em ferramenta on-line gratuita $\left.{ }^{4}\right]$, o questionário incluía 59 perguntas (sendo 42 fechadas e 17 abertas), divididas em seis seções :

- a primeira era composta por perguntas acerca do perfil das participantes, incluindo : gênero de identificação, raça/cor, deficiência, idade, quantidade de filhos, idade dos filhos, estado e cidade de residência, pessoas com quem residiam e se alguma destas necessitava de cuidados especiais, escolaridade, profissão, principal ocupação, renda líquida individual e familiar e adesão ao isolamento social na ocasião da pesquisa ;

- a segunda seção buscava compreender se as participantes possuíam um trabalho remunerado antes e durante a pandemia e, se fosse o caso, a duração de suas jornadas de trabalho ;

- a terceira seção objetivava apreender acerca do trabalho doméstico das participantes no período anterior e durante o isolamento social : quem eram os responsáveis pelas tarefas de cuidado com a casa (tais como preparo das refeições, limpeza do chão, móveis e banheiros, cuidados com as roupas e administração de empregados, se fosse o caso), tempo médio gasto por dia com estas atividades, sentimentos em relação a este trabalho e satisfação em relação à divisão de tarefas com outros adultos ; 
- a quarta seção buscava compreender quem eram os responsáveis pelas tarefas de cuidado das crianças (tais como asseio, alimentação, rotina de sono, entretenimento, apoio nas tarefas escolares, atenção à saúde física e emocional e administração da rotina geral de cuidados) antes e durante a pandemia, incluindo questões sobre frequência semanal e tempo de dedicação dos cuidadores ;

- a quinta seção dedicava-se a perguntas específicas sobre as instituições escolares, questionando: se os filhos estavam matriculados em creches ou escolas no período anterior ao isolamento social; se a escola estava propondo atividades remotas (e, se fosse o caso, quem era o responsável pelo acompanhamento destas atividades); se tais atividades estariam ajudando ou atrapalhando a rotina de cuidados dos filhos;

- a sexta e última seção continha perguntas relacionadas à satisfação com o trabalho de cuidado dos filhos, incluindo: prazeres e dificuldades relacionados a estas tarefas, consequências boas e ruins da quarentena para a maternidade, sensações em relação ao volume deste trabalho e à divisão destas tarefas com outras pessoas durante a pandemia. Ao final do questionário, havia ainda um espaço livre para comentários gerais.

Para responder às perguntas, as participantes precisavam acessar um link a partir de algum equipamento digital com acesso à internet. A chamada para participação na pesquisa esclarecia o objetivo da mesma e ressaltava o critério para a participação : ser mãe de pelo menos um(a) filho(a) com idade igual ou inferior a 12 anos. A primeira página da pesquisa destacava que a participação era voluntária e que o sigilo das participantes seria garantido [5].

A divulgação do link do questionário foi feita no site da organização que promoveu a iniciativa 'Laboratório de Emergência COVID-19', pela autora e por outros nove colaboradores voluntários em redes sociais relacionadas à temática da maternidade $\mathrm{e}$ via aplicativo de troca de mensagens por celular [ $\left.{ }^{6}\right]$. A amostragem foi composta, assim, a partir do método 'bola de neve' (Coleman, 1958; Goodman, 1961), que consiste em selecionar algumas pessoas que fazem parte da população-alvo como primeiros respondentes e solicitar que elas indiquem, dentre seus contatos, outros indivíduos para compor a amostra. No caso da pesquisa em questão, foi solicitado que as próprias participantes encaminhassem o link do questionário para outras mães. Ainda que o método de amostragem em bola de neve seja tipicamente utilizado para pesquisas com populações raras ou desconhecidas, mais difíceis de encontrar ou contatar, optou-se por recorrer a ele em razão do contexto de isolamento social, que restringiu o uso de outras ferramentas que exigissem encontros presenciais.

\subsection{0 perfil das participantes}

Ao todo, o levantamento obteve 360 respostas válidas (foram excluídas as participantes que não satisfaziam o critério de participação), entre os dias 2 e 25 de maio de 2020. Deste total : as brancas perfizeram $73 \%$, enquanto as pardas e negras corresponderam a $25 \%$ e as amarelas, a $2 \%$; apenas $13 \%$ não possuíam Ensino Superior completo, $27 \%$ haviam concluído a graduação, $31 \%$ tinham pós-graduação completa, $16 \%$ fizeram mestrado e $13 \%$, doutorado ; a maioria (65\%) contava com renda familiar mensal acima de cinco salários-mínimos, conforme explicitado na Tabela 1. 
Tabela 1 : Percentual de respondentes de acordo com a renda familiar mensal



Tabela 1 : Percentual de respondentes de acordo com a renda familiar mensal

30 As respondentes tinham entre 21 e 51 anos, sendo 37 a média de idade ; 61 \% possuíam um filho, 34 \% eram mães de dois e apenas $5 \%$, de três ou mais filhos. A maioria (59 \%) tinha filhos de até 5 anos de idade.

31 Apenas $1 \%$ declarou-se portadora de alguma deficiência e $9 \%$ afirmaram residirem com pessoas que necessitam de cuidados especiais (em função de idade avançada, doença ou alguma outra questão de saúde). A pesquisa recebeu respostas de mães que residiam em 18 estados brasileiros, a maioria (81\%) na região Sudeste, sendo 49 \% no Rio Janeiro, 17 \% em Minas Gerais, 12 \% em São Paulo e 3 \% no Espírito Santo. As demais respondentes eram das seguintes regiões : $8 \%$ do Nordeste, $6 \%$ do Sul, $3 \%$ do Norte e $2 \%$ do Centro-Oeste.

32 Grande parte destas mães (92\%) estava em isolamento social na ocasião da pesquisa, declarando não sair de casa ou fazendo-o apenas eventualmente (em casos de urgência ou para ir ao mercado, à farmácia ou a consultas médicas). A maioria das respondentes (73\%) estava residindo com seus companheiros e com os filhos ; 13 \% moravam apenas com os filhos ; $14 \%$ viviam com os filhos e outros adultos (excluindo os companheiros).

\subsection{0 trabalho remunerado}

33 No período anterior ao isolamento social, $84 \%$ das mães respondentes possuíam um trabalho remunerado, sendo que $55 \%$ tinham carteira assinada ou eram servidoras públicas, 23 \% eram autônomas ou contratadas como pessoa jurídica e 6 \% possuíam um negócio próprio. Na ocasião da pesquisa, 68 \% das participantes estavam mantendo este trabalho e, dentre estas, apenas $7 \%$ estavam trabalhando presencialmente, enquanto as demais trabalhavam de maneira remota. Para grande parte destas mães, houve uma redução da carga horária semanal de dedicação a este trabalho, conforme demonstra a Tabela 2. 
Tabela 2 : Percentual de participantes conforme a carga horária semanal de dedicação ao trabalho remunerado

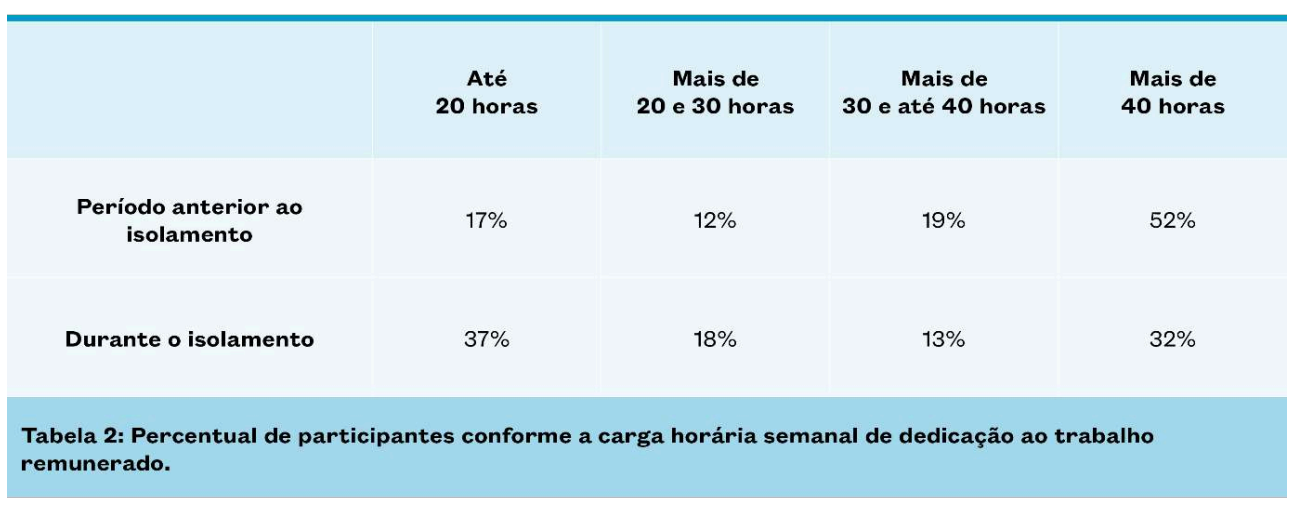

Tabela 2 : Percentual de participantes conforme a carga horária semanal de dedicação ao trabalho remunerado

Ainda que não haja a intenção de dar conta da complexidade e da diversidade de situações em que se encontravam as respondentes no momento do levantamento, arriscamos alguns possíveis motivos para a redução da carga horária de trabalho remunerado destas mulheres : a diminuição de demandas das empresas/instituições contratantes; a diminuição das demandas diretas dos clientes, especialmente no caso de mães autônomas ou que possuíam um negócio próprio; e a necessidade de redimensionar a carga horária de trabalho remunerado para dar conta de outras demandas intensificadas no período de quarentena - as tarefas de cuidado da casa e dos filhos. Esta última possibilidade será desenvolvida nas seções a seguir.

\subsection{O trabalho doméstico de cuidado da casa e dos filhos}

Um percentual significativo das participantes ( $43 \%$ ) declarou que, no período anterior à quarentena, as tarefas relativas ao cuidado da casa - como o preparo das refeições, a limpeza de chão, móveis e banheiros e a lavagem das roupas - eram realizadas principalmente por empregadas domésticas (mensalistas ou diaristas), percentual que caiu para $4 \%$ na ocasião da pesquisa. A Tabela 3 apresenta os responsáveis pelo trabalho doméstico no período anterior à pandemia e durante o isolamento social. 
Tabela 3 : Responsáveis pelo trabalho doméstico de cuidado da casa

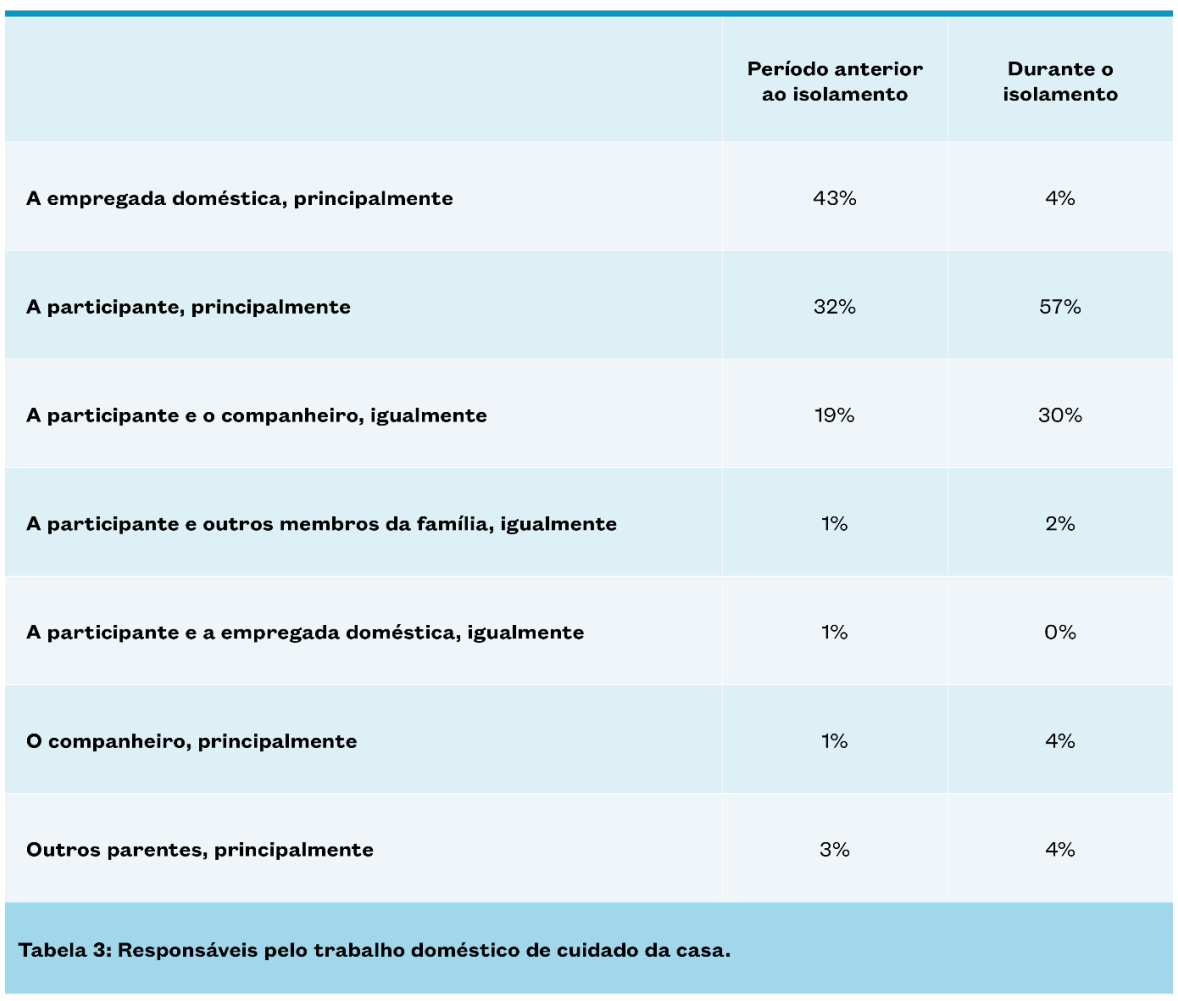

Tabela 3 : Responsáveis pelo trabalho doméstico de cuidado da casa

Cabe observar o aumento, durante o isolamento, da atuação das participantes e companheiros, igualmente, no trabalho doméstico de cuidado da casa, já que os valores passaram de $19 \%$ a $30 \%$. Ainda assim, uma parcela significativa do trabalho doméstico que vinha sendo delegado a empregadas tornou-se incumbência principalmente das mães durante o isolamento. A dispensa (remunerada ou não) destas trabalhadoras e o maior volume de tarefas domésticas durante a pandemia refletem-se no aumento da quantidade de horas dedicadas pelas participantes ao trabalho doméstico, conforme a Tabela 4.

Tabela 4 : Percentual de participantes conforme a carga horária de dedicação ao trabalho doméstico de cuidado da casa

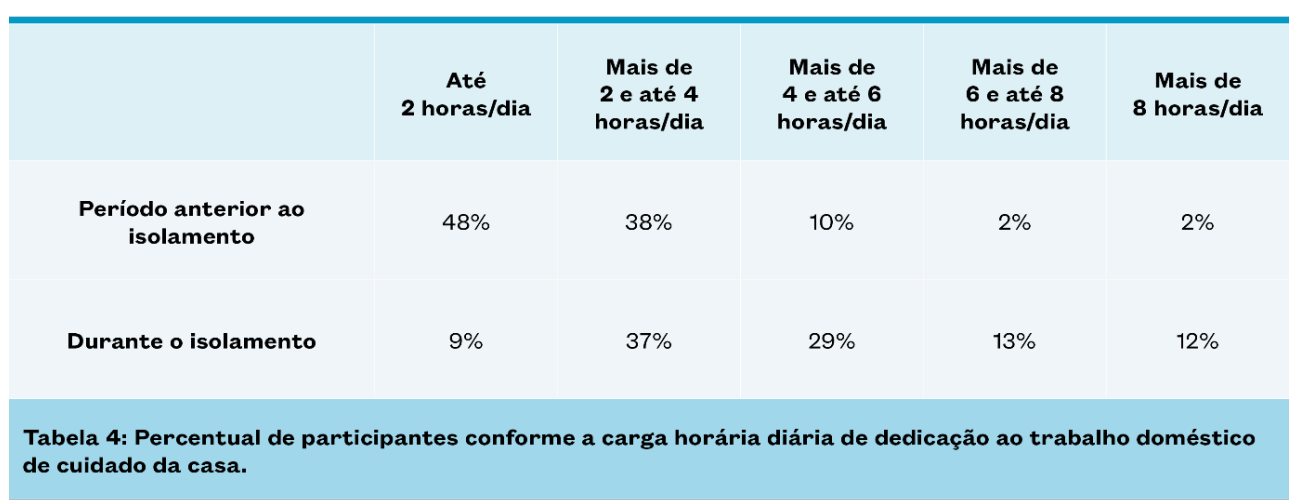

Tabela 4 : Percentual de participantes conforme a carga horária de dedicação ao trabalho doméstico de cuidado da casa 
Como as famílias, em geral, passaram a permanecer mais tempo no lar, o isolamento intensificou não apenas o trabalho de cuidado relacionado à casa, mas também aquele relacionado às crianças. As tabelas a seguir explicitam a frequência com que cada cuidador se dedicava a este trabalho $\left.{ }^{7}\right]$ no período anterior ao isolamento (Tabela 5) e na ocasião da pesquisa (Tabela 6), segundo a perceção das participantes.

Tabela 5 : Responsáveis pelo trabalho de cuidado das crianças no período anterior ao isolamento social

\begin{tabular}{|c|c|c|c|c|c|c|}
\hline & $\begin{array}{l}\text { Todos os } \\
\text { dias }\end{array}$ & $\begin{array}{c}5 \text { ou } 6 \\
\text { vezes/ } \\
\text { semana }\end{array}$ & $\begin{array}{c}3 \text { ou } 4 \\
\text { vezes/ } \\
\text { semana }\end{array}$ & $\begin{array}{c}1 \text { ou } 2 \\
\text { vezes/ } \\
\text { semana }\end{array}$ & $\begin{array}{l}\text { Menos } \\
\text { de } 1 \text { vez/ } \\
\text { semana }\end{array}$ & Nunca \\
\hline Mãe & $71 \%$ & $5 \%$ & $11 \%$ & $11 \%$ & $1 \%$ & $0 \%$ \\
\hline $\begin{array}{l}\text { Pai da criança ou o atual } \\
\text { companheiro }\end{array}$ & $39 \%$ & $4 \%$ & $13 \%$ & $21 \%$ & $11 \%$ & $11 \%$ \\
\hline Empregada doméstica/babá & $5 \%$ & $8 \%$ & $6 \%$ & $8 \%$ & $4 \%$ & $68 \%$ \\
\hline Outros parentes & $6 \%$ & $3 \%$ & $7 \%$ & $11 \%$ & $20 \%$ & $52 \%$ \\
\hline Vizinhos/ amigos & $1 \%$ & $0 \%$ & $0 \%$ & $1 \%$ & $5 \%$ & $92 \%$ \\
\hline $\begin{array}{l}\text { Nota: } 1 \% \text { das participantes teve } \\
\text { por linha contabiliza } 99 \% .\end{array}$ & eiro filho d & te o pe & do isola & to social. & este moti & o total \\
\hline
\end{tabular}

Tabela 5 : Responsáveis pelo trabalho de cuidado das crianças no período anterior ao isolamento social 
Tabela 6 : Responsáveis pelo trabalho de cuidado das crianças na ocasião da pesquisa

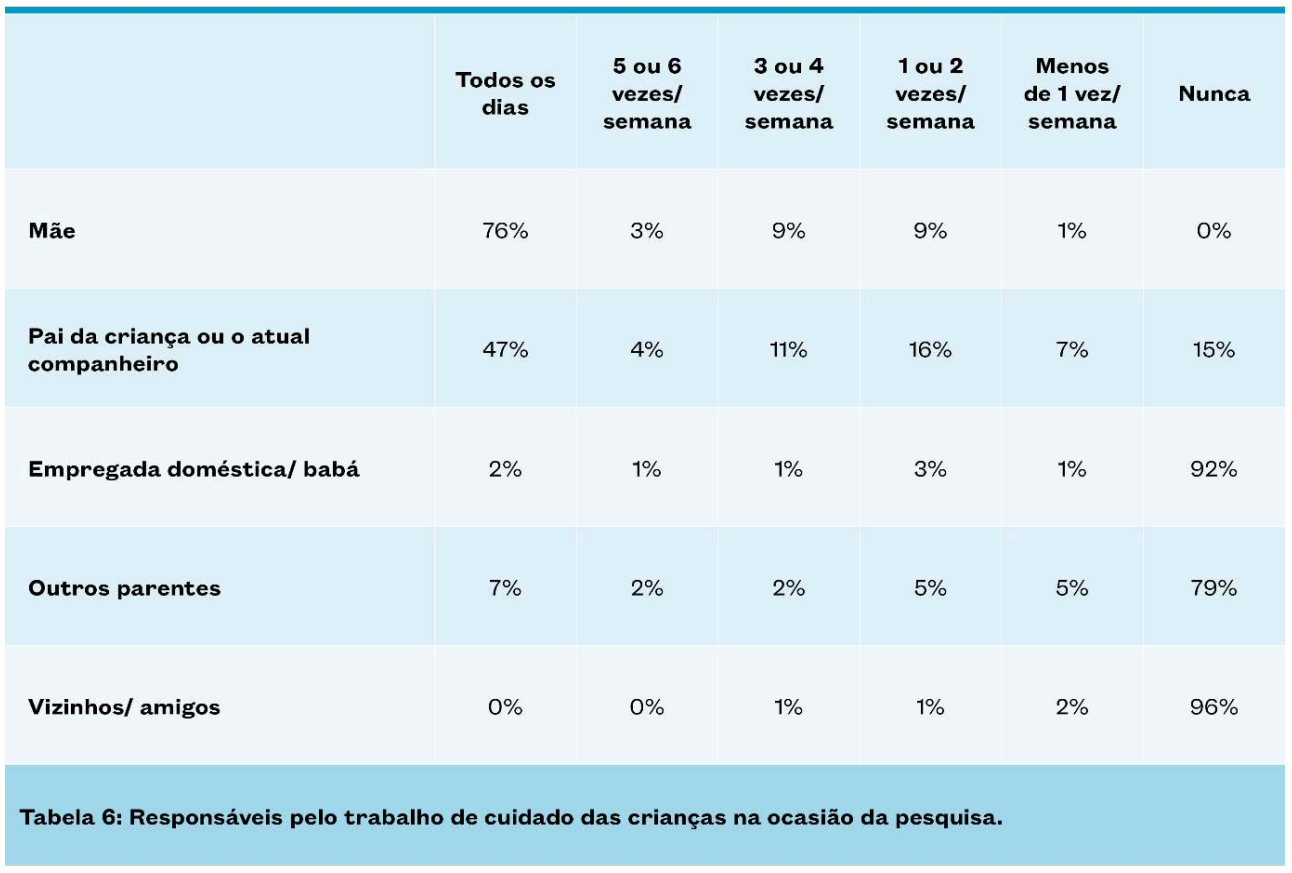

Tabela 6 : Responsáveis pelo trabalho de cuidado das crianças na ocasião da pesquisa

Quando se comparam os dois períodos, é possível verificar que :

- as mães já se dedicavam aos cuidados diários dos filhos em $71 \%$ dos lares e durante o isolamento esse percentual passou a $76 \%$;

- houve um aumento do percentual dos pais/companheiros que se dedicavam diariamente aos cuidados das crianças, de $39 \%$ para $47 \%$. Não obstante, esse percentual manteve-se bastante inferior ao das mães ;

- 27 \% das famílias contavam com o trabalho de empregadas domésticas/babás pelo menos uma vez por semana. $\mathrm{Na}$ ocasião da pesquisa, apenas $7 \%$ seguiam contando semanalmente com este trabalho;

- no período anterior à quarentena, $27 \%$ das mães contavam com o apoio de outros parentes para os cuidados dos filhos pelo menos uma vez por semana, percentual que caiu para $16 \%$ durante o isolamento.

Assim, suportes importantes de cuidado tornaram-se menos acessíveis durante o período de isolamento social, como a rede de apoio familiar e/ou o trabalho de empregadas domésticas/babás. Além disso, as instituições de ensino, que integravam os arranjos de cuidado para a maioria das famílias pesquisadas, tornaram-se indisponíveis: enquanto no período anterior à pandemia $90 \%$ das crianças frequentavam escolas ou creches (sendo $63 \%$ em meio período e $27 \%$ em período integral), no momento da pesquisa nenhuma delas estava frequentando as instituições, fechadas no início da pandemia.

A falta de acesso a outros provedores de cuidado - ou a sua significativa redução parece ter sido, em grande medida, compensada pela maior quantidade de horas dispensadas pelas mães aos cuidados dos filhos : se antes $23 \%$ dedicavam mais de oito horas por dia a este trabalho, este percentual triplicou durante a quarentena, atingindo $69 \%$ das participantes, conforme especifica a Tabela 7. 
Tabela 7 : Percentual de participantes conforme a carga horária diária de dedicação ao trabalho doméstico de cuidado dos filhos

\begin{tabular}{|c|c|c|c|c|c|}
\hline & $\begin{array}{c}\text { Até } \\
2 \text { horas/dia }\end{array}$ & $\begin{array}{c}\text { Mais de } \\
2 \text { e até } 4 \\
\text { horas/dia }\end{array}$ & $\begin{array}{c}\text { Mais de } \\
4 \text { e até } 6 \\
\text { horas/dia }\end{array}$ & $\begin{array}{c}\text { Mais de } \\
6 \text { e até } 8 \\
\text { horas/dia }\end{array}$ & $\begin{array}{c}\text { Mais de } \\
8 \text { horas/dia }\end{array}$ \\
\hline $\begin{array}{l}\text { Período anterior ao } \\
\text { isolamento }\end{array}$ & $8 \%$ & $28 \%$ & $30 \%$ & $11 \%$ & $23 \%$ \\
\hline Durante o isolamento & $3 \%$ & $7 \%$ & $11 \%$ & $10 \%$ & $69 \%$ \\
\hline
\end{tabular}

Tabela 7 : Percentual de participantes conforme a carga horária diária de dedicação ao trabalho doméstico de cuidado dos filhos

Em grande parte dos lares, não houve apenas um aumento da quantidade de horas dedicadas ao trabalho de cuidado, mas também um acréscimo em seu conteúdo e/ou a necessidade de lidar com desafios suplementares impostos pela pandemia, como declarou a assistente social, moradora de Queimados (RJ) e mãe de dois filhos (com idades entre 3 e 8 anos) : "Somaram aos cuidados normais novas funções". A seção a seguir é dedicada a estes desafios.

\subsection{Maternidade em quarentena : principais desafios}

m resposta à pergunta aberta "quais têm sido seus principais desafios/dificuldades relacionados ao cuidado dos seus filhos durante o isolamento ?", diversos aspetos foram citados pelas participantes, sendo três deles recorrentes.

\subsubsection{Acompanhar as tarefas escolares}

O Brasil está entre os países que permaneceram com as escolas fechadas por mais tempo durante o primeiro semestre de $\left.2020{ }^{8}\right]$. Em função disso, algumas instituições de ensino, especialmente as particulares, adotaram estratégias alternativas para o cumprimento do ano letivo, como o ensino remoto. Nos lares pesquisados, $77 \%$ das crianças matriculadas em escolas ou creches estavam recebendo propostas de atividades remotas pelo menos uma vez por semana (se considerarmos apenas as escolas públicas, esse percentual cai para $67 \%$ ). Estas atividades, que frequentemente demandavam a supervisão de um adulto, estavam sendo acompanhadas pelas mães em $58 \%$ destes lares; em $15 \%$ havia um revezamento entre os genitores e em apenas $4 \%$ era o pai o principal responsável pela função. Assim, para muitas destas mães, as instituições de ensino não apenas deixaram de ser um suporte para o cuidado das crianças, mas também transferiram para elas parte de suas funções.

Quando questionadas se as tarefas escolares remotas estariam ajudando ou atrapalhando a rotina de cuidados dos filhos, estas participantes tinham uma perceção diversificada: $57 \%$ responderam que ajudavam; $32 \%$ afirmaram que as atividades atrapalhavam ; $7 \%$ disseram que não ajudavam nem atrapalhavam ou que às vezes ajudavam e às vezes atrapalhavam; $3 \%$ das respondentes disseram que os filhos não 
estavam realizando as tarefas, por falta de interesse ou falta de disponibilidade de quem pudesse assessorá-los ; $1 \%$ não soube avaliar.

Marina é arquiteta e mora com a filha, que tem entre 6 e 8 anos, no Rio de Janeiro (RJ). O pai, que não reside com elas, assume os cuidados da criança menos de uma vez por semana. Trabalhando de casa e tendo assumido as tarefas domésticas que antes ficavam a cargo de uma empregada, Marina está entre os $57 \%$ com uma perceção positiva acerca das atividades escolares, mas pondera :

\footnotetext{
"Estou sozinha pra fazer tudo e ainda tenho que fazer aulas on-line com a minha filha de 6 anos que ainda se distrai muito se ficar sozinha na frente do computador. [...] Acredito que diminui a ansiedade da criança e isso ajuda de um modo geral, mas também prejudica no sentido que acaba me sobrecarregando, já que não tenho com quem dividir esse acompanhamento".
}

Para Vivian, bancária que também mora sozinha com a filha, em Brasília (DF), as tarefas escolares estavam atrapalhando a rotina da família. Até a pandemia, ela contava com uma empregada, que era a principal responsável pelas tarefas da casa e pelo cuidado da criança. Na ocasião da pesquisa, Vivian tinha assumido sozinha todo o trabalho doméstico, incluindo o acompanhamento escolar da filha, uma vez que o pai não tem qualquer participação nos cuidados da criança: "Minha filha tem 4 anos, precisa ser assistida e as aulas são ao vivo e no mesmo horário em que eu estou em home-office. É um caos, ela odeia, eu me estresso. Já meio que desisti dessas aulas".

Rosa é dona de casa e reside em São Paulo (SP) com os três filhos, com idades entre 6 e 10 anos, e o companheiro. Responsável pelo acompanhamento das atividades escolares das crianças, ela ressaltou as dificuldades em assumir a função: "Eu não tenho conhecimento e didática para ajudar e ensinar as matérias para eles. Com isso, ficamos todos estressados, eles choram, eu choro, e sei que eles não estão aprendendo absolutamente nada".

\subsubsection{Manter os filhos entretidos}

Além das dificuldades em relação às tarefas escolares, muitas participantes citaram outro desafio : manter os filhos entretidos. Para elas, 'brincar', 'dar atenção' e/ou 'tempo de qualidade' foram dificultados em função da necessidade de assumir outras tarefas, da impossibilidade de sair de casa ou da falta de interação da criança com outras pessoas. Para entreter os filhos, várias mães afirmaram estar fazendo uso de telas mais do que elas gostariam.

Para Ângela, que mora sozinha no Rio de Janeiro (RJ) com a filha, que tem entre 11 e 12 anos, a maior dificuldade era "ser criativa para inventar novas atividades e combater o tédio de uma criança em casa o tempo todo". Jornalista, ela estava trabalhando remotamente por mais de 45 horas semanais na ocasião da pesquisa, mas contava com uma empregada doméstica para as atividades relativas à casa. Serena mora no Rio de Janeiro (RJ), é professora universitária e divide com o companheiro as tarefas de cuidado da casa e do filho, mas, em função do ritmo de trabalho remunerado, citou que o maior desafio era "relaxar para brincar tendo trabalho acumulado". Carmen também é professora, mora no Rio de Janeiro (RJ), e descreve seu companheiro como um pai "presente e ativo" para seus dois filhos, que têm entre 3 e 5 anos, mas, em função da sobrecarga das tarefas da casa, que recaíram sobre ela, confessou : "o ânimo para brincadeira está pequeno". 


\subsubsection{Gerir os conflitos entre trabalho produtivo e reprodutivo}

50 As tensões relativas à incumbência simultânea às mulheres de responsabilidades profissionais e familiares são, como já sinalizado, anteriores à pandemia. No entanto, o isolamento social parece ter intensificado esta contradição ao confinar, no mesmo tempo e espaço, trabalho produtivo e reprodutivo e tornar menos acessíveis os arranjos de cuidado que vinham sendo praticados por algumas famílias até então. Por serem as mães que normalmente 'conciliam' estes trabalhos, a provisão de cuidados pelas instituições de ensino e/ou a sua delegação a outras pessoas - em geral, mulheres influenciam de maneira significativa a possibilidade e a qualidade de dedicação dessas mulheres aos seus trabalhos remunerados.

51 Depoimentos de mães que estavam residindo apenas com os filhos durante o isolamento social ilustram as dificuldades de gerir conjuntamente trabalho produtivo e reprodutivo, como é o caso de Maria. Consultora de comunicação e marketing, ela mora em Belo Horizonte (MG) com o filho, que tem idade entre 9 e 10 anos, e ressaltou :
"Carga mental alta, muito tempo para cuidado dele [filho] que atrapalha meu tempo de trabalho, é muito cansativo. Não sinto estar fazendo nenhum trabalho meu de maneira adequada, nem aproveito o tempo com ele bem por estar sempre dividida entre várias funções".

Cláudia trabalha com assessoria parlamentar, também reside em Belo Horizonte (MG) com seus dois filhos pequenos (com idades entre 1 e 5 anos) e declarou: "Tenho que cuidar das crianças e fazer meu trabalho em home-office ao mesmo tempo. Isso é enlouquecedor! As crianças precisam de atenção e meu trabalho exige concentração". No período anterior à pandemia, ela contava com o suporte da escola e de parentes para os cuidados dos filhos.

Este também é o caso de Lia, jornalista e editora que mora no Rio de Janeiro (RJ). Mesmo dividindo as tarefas de cuidado dos dois filhos (que têm entre 1 e 5 anos) com o marido, destacou a falta de outros suportes: "Não tem creche, não tem babá, não tem diarista, não tem vovó".

Conforme sinalizam Sorj e Fontes (2012) :

“É possível supor que a delegação de cuidados das crianças, nas famílias em que as mães trabalham, combina arranjos diferentes segundo a classe social. Nas famílias mais abastadas, alia-se a frequência às creches e pré-escolas particulares com o serviço das trabalhadoras domésticas, enquanto nas famílias de baixa renda os cuidados das crianças são compartilhados pelas instituições de educação infantil públicas e os cuidados informais feitos por parentes" (p. 112).

A importância das instituições escolares para a gestão conjunta do trabalho remunerado e dos cuidados dos filhos é ressaltada por diversas participantes, como Catarina, publicitária que reside em São Paulo (SP) com o companheiro e o filho, com idade entre 1 e 2 anos : "Sem a creche, e como autônoma que já trabalhava em casa, sinto que perdi meu tempo para trabalhar e quase surtei tendo que trabalhar somente quando meu filho dorme". Elisa, professora que reside em Florianópolis (SC) com o marido e os dois filhos (com idades entre 3 e 5 e 9 e 10 anos), explicou como a falta da escola tem impacto na gestão conjunta dos trabalhos remunerado e doméstico: "O tempo que eles ficavam no 
colégio era o tempo em que eu estava trabalhando. Agora todos em casa, não tem divisão de horário". e de executivas, aliado às novas formas de gestão das empresas - que exigem um envolvimento pessoal cada vez maior -, faz surgir ao mesmo tempo, dentre as mais abonadas, a necessidade e os meios de delegar a outras mulheres as tarefas domésticas e familiares. Nessas famílias, o 'modelo da delegação' substitui ou se sobrepõe ao 'modelo da conciliação vida familiar/vida profissional' : para conseguirem realizar seu trabalho profissional, essas mulheres precisam externalizar 'seu' trabalho doméstico e recorrem, frequentemente, a mulheres em situação precária - no caso do Brasil, sobretudo nos segmentos mais privilegiados, esses afazeres têm sido providos frequentemente por trabalhadoras domésticas, atividade que remonta ao período colonial e à escravidão. Sorj e Fontes (2012) também acreditam que :

\footnotetext{
“o acesso de mulheres de classe média e alta ao serviço realizado pelas trabalhadoras domésticas é, provavelmente, um dos fatores determinantes do crescente afluxo e permanência de mulheres de classe média e alta em empregos com carreira, melhor remuneração e prestígio social verificado nas últimas décadas" (p. 109).
}

Para levar à frente seus projetos profissionais, essas mulheres precisam, então, dispor de uma "rede de substituição infalível ; mais do que o recurso ao cônjuge, a organização familiar repousa sobre ajudas externas" (Foureroyllas-Schwebel, 2009, p. 260). Para os casais burgueses, a externalização das tarefas domésticas a empregadas tem ainda uma função de apaziguamento das tensões relativas à distribuição desigual deste trabalho entre os sexos, permitindo igualmente maior flexibilidade das mulheres em relação às demandas do mercado de trabalho produtivo. Isso permite que se faça 'vista grossa' no que diz respeito a uma reflexão sobre o trabalho doméstico :

\footnotetext{
"Mas essa pacificação das relações sociais nos casais e nas empresas não ajuda a avançar nem um pouco na luta pela igualdade. Ao contrário, ela tem sobretudo uma função regressiva a esse respeito, pois funciona no nível do mascaramento e da negação" (Hirata \& Kergoat, 2007, p. 602).
}

Ao impor, no entanto, uma interrupção nos arranjos anteriores à pandemia, o contexto de isolamento parece ter feito ressurgir, para algumas famílias, a velha problemática do antagonismo entre responsabilidades familiares e profissionais, quase sempre mal resolvida, mas apaziguada nos lares que, até então, contavam com o trabalho de domésticas/babás (Hirata \& Kergoat, 2007). A dispensa das trabalhadoras domésticas retomou ainda, para alguns casais, as tensões relativas à má distribuição do trabalho doméstico entre os sexos - quem assumiu o trabalho que vinha sendo delegado para elas ? O aumento significativo da quantidade de horas dedicadas pelas participantes da pesquisa ao trabalho doméstico de cuidado da casa e dos filhos faz supor que, em grande parte dos lares, foi para elas que este trabalho 'retornou'. 


\subsection{A divisão do trabalho reprodutivo entre os sexos}

60 da casa, $49 \%$ das participantes que estavam residindo com seus companheiros declararam estar satisfeitas, contra $51 \%$ que se disseram insatisfeitas. As queixas foram frequentes nos depoimentos das participantes, como é o caso de Júlia, arquiteta e cenógrafa que reside com o marido e os dois filhos, que têm entre 3 e 8 anos, no Rio de Janeiro (RJ) :

"Eu trabalhava em tempo integral e o cuidado da casa era dividido com uma ajudante. Agora $80 \%$ é comigo, $15 \%$ com meu marido e $5 \%$ as crianças ajudam como podem. [...] As tarefas do trabalho vão começar em breve, e ainda não quero pensar em como vai ser pra dar conta de tudo".

61 Rita, zootecnista residente em Palmas (TO), ressalta : "Não estamos dividindo o trabalho doméstico. 0 marido 'só ajuda'. Não reveza". Mãe de dois filhos, com idades entre 3 e 8 anos, ela contava com uma empregada doméstica no período anterior à pandemia, mas, na ocasião da pesquisa, tinha assumido a maior parte das tarefas da casa, além de estar trabalhando remotamente, ainda que com carga horária reduzida. Ana, analista de Recursos Humanos, residente no Rio de Janeiro (RJ) e mãe de um filho, com idade entre 1 e 2 anos, relatou que, no período anterior à pandemia, ela e o marido dividiam igualmente todas ou quase todas as tarefas relativas à casa. A divisão do trabalho doméstico entre o casal piorou, no entanto, durante o isolamento social : "Como estou trabalhando de casa, o marido acaba achando que estou mais descansada". Catarina reside em São Paulo (SP), tem trabalhado apenas nos momentos em que o filho de 1 ano está dormindo e também estava insatisfeita com a divisão do trabalho doméstico, que no período anterior ao isolamento era repartido com o marido e uma diarista. Responsável pela maior parcela deste trabalho na ocasião da pesquisa, ela se queixou : "Sinto que faço muito mais e meu companheiro não acha".

Tais depoimentos sugerem que, nestes lares, não foram apenas os arranjos de delegação do trabalho doméstico que foram desfeitos, mas também os arranjos de parceria que existiam entre alguns casais. No momento em que estas mulheres voltaram a permanecer mais tempo em casa, a divisão igualitária das tarefas domésticas deu lugar aos arranjos tradicionais - em que as mulheres assumem todo este trabalho, enquanto os homens se dedicam ao trabalho produtivo - ou aos arranjos de conciliação - em que apenas elas são responsáveis pela gestão conjunta dos trabalhos produtivo e reprodutivo.

No que tange especificamente à divisão das tarefas de cuidado dos filhos, $54 \%$ das participantes disseram estar insatisfeitas com os arranjos estabelecidos com seus companheiros/pais das crianças, enquanto $46 \%$ declararam estar satisfeitas. A insatisfação com a divisão desigual dos cuidados das crianças foi registrada em depoimentos de diversas participantes, como o de Cora, arquiteta que mora em Brasília com o marido e a filha, que tem entre 1 e 2 anos :

“As tarefas não estão divididas igualmente, fico a maior parte do tempo cuidando da criança e, quando necessito de um tempo para mim, quando o pai está em casa nem sempre é possível. Porque está cansado, mas eu também estou cansada e não tenho a opção de não cuidar da nossa filha". 
64 A fala de Cora ressaltou a expectativa de, assim como o marido, alternar entre trabalho e descanso, e colocou em relevo uma particularidade relativa ao trabalho de cuidado de uma criança pequena : diferentemente do trabalho produtivo, esta alternância só é possível quando existem outros cuidadores. A distribuição desigual do tempo de descanso entre o casal também é sentida por Isabel, analista ambiental que reside em Belo Horizonte (MG) com o marido e o filho, que tem entre 6 meses e 1 ano: "Sinto que meu companheiro se isenta de algumas atividades e tira folga aos finais de semana". Durante o isolamento, ela estava trabalhando remotamente com carga horária superior a 45 horas por semana, além de ter aumentado a sua dedicação diária aos cuidados da casa e do filho.

Uma pesquisa global com 18 países realizada em maio de 2020 pelo Instituto IPSOS (2020) apontou que a pandemia da COVID-19 parece ter aumentado o abismo na divisão entre os sexos de tarefas não remuneradas. Considerando o total de países pesquisados, as mulheres tinham, em média, $4 \%$ mais probabilidade do que os homens de dizer que concordavam fortemente com a seguinte afirmação: 'Tive que assumir muito mais responsabilidade pelas tarefas domésticas e cuidar de crianças e familiares durante esta pandemia'. Segundo a própria pesquisa, a realidade pode, no entanto, ser ainda mais desigual, uma vez que estudos anteriores mostram que as mulheres tendem a subestimar o tempo e a energia que dedicam para cuidar dos outros, enquanto os homens, ao contrário, tendem a superestimar.

\subsection{A sobrecarga e a exaustão}

66 A necessidade de gerir uma quantidade desproporcional de trabalho doméstico, frequentemente em conjunto com o trabalho remunerado, pode explicar a recorrência de alguns termos nas respostas às perguntas abertas do questionário : 'sobrecarga' ou 'sobrecarregada' apareceram 79 vezes ao longo da pesquisa; 'cansaço' ou 'cansada' foram citados 53 vezes; 'exaustão' ou 'exausta', 20 vezes. Esses termos não apenas reforçam as dificuldades encontradas em virtude da sobreposição dos trabalhos reprodutivo e produtivo e da impossibilidade de alternância entre trabalho e não trabalho, mas também contrastam com uma visão comumente eufemizada das tarefas domésticas, em especial aquela relativa ao cuidado das crianças, muitas vezes visto exclusivamente como fonte de prazer, amor e ternura. Frequentemente considerado ameno, rotineiro e limitado a respostas instrumentais, o trabalho de cuidado desenrolase, na realidade, sob um regime intenso de contraintes [ ${ }^{9}$ ] corporais e mentais, especialmente quando é endereçado a pessoas dependentes, como as crianças pequenas : aqueles que dependem de nós, justamente por sua dependência, nos impõem os seus ritmos e, assim, contrariam e entravam nossos desejos (Molinier, 2004b). Esse regime de contraintes intensificou-se durante a quarentena, em função do aumento do volume de trabalho de cuidado da casa e dos filhos e da diminuição da possibilidade de dividir este trabalho - e suas agruras - com outras pessoas.

67 Michelle é professora e mora em Rio Paranaíba (MG) com o marido e o filho, que tem entre 1 e 2 anos. Durante a pandemia, teve sua carga de trabalho remunerado diminuída, mas aumentou a sua dedicação aos cuidados da casa e do filho, que antes frequentava uma creche em meio período. Insatisfeita com a divisão das tarefas de cuidado da criança entre ela e o marido, declarou : "Não há tempo de descanso. Com uma 
criança pequena, é preciso estar alerta, atenta a barulhos e movimentações, e estar $100 \%$ do tempo em estado de alerta é desgastante física e emocionalmente".

Maternar uma criança pequena frequentemente exige uma mobilização subjetiva constante, mesmo quando se está distante do filho (Dorna, 2018). A maior proximidade das crianças durante o isolamento social e a impossibilidade de dividir os seus cuidados com outras pessoas tendem a acentuar esta exigência.

Rosa já era a principal responsável pelo trabalho doméstico, mas seus três filhos frequentavam a escola por meio período. Durante o isolamento, ela passou a permanecer sozinha com as crianças o dia inteiro, enquanto o marido estava trabalhando presencialmente :

"Vinte e quatro horas por dia em função deles, sem tempo para ir ao banheiro sozinha, eles querem comer o dia todo, aí tem louça o dia todo, escola [on-line], banheiros, quartos, tudo para fazer com eles atrás, bem complicado e estressante. Toda mãe precisa ter um tempo pra ela e na quarentena isso é impossível".

70 A necessidade de ter um tempo para si é citada por várias participantes. Nina é professora, mas não estava exercendo trabalho remunerado durante o isolamento social. Mãe de um filho com idade entre 1 e 2 anos, ela reside com o marido no Rio de Janeiro (RJ) e já era a principal responsável pelo trabalho doméstico de cuidado da casa e da criança, mas se queixa da divisão das tarefas com o companheiro : "Falta iniciativa, não gostaria de ter que pedir ajuda todo tempo. [...] Só gostaria de conseguir ter um tempinho pra poder respirar, conseguir fazer algo só pra mim, cuidar de mim, alguns momentos na semana seriam incríveis".

71 "Minhas necessidades ficam sempre por último", desabafa Míriam que, além de trabalhar remotamente em um projeto de empreendedorismo materno, manteve-se como a principal responsável pelo trabalho doméstico na casa em que vive com o marido e o filho, que tem entre 3 e 5 anos, em Curitiba (PR). Esses depoimentos revelam como a dependência daquele que é cuidado frequentemente exige do cuidador uma certa renúncia de si e de suas próprias necessidades. Na relação mãe e filho, esta renúncia é naturalizada e romantizada, visto que a maternidade segue associada ao ideal de sacrifício, muito difundido a partir do século XIX, quando o sofrimento materno passou a ser considerado condição para a felicidade do rebento (Badinter, 1985). Mesmo que na atualidade haja mais espaço para que mães possam expressar suas dificuldades e angústias, a maternidade continua sendo capturada no imaginário coletivo como uma relação livre de conflitos interpessoais, o que faz com que haja, portanto, uma certa proibição tácita de evocar os sentimentos negativos que ela possa suscitar. Cuidar dos outros não é forçosamente agradável - ao contrário, pode despertar raiva e aversão. A ambivalência e a flutuação de sentimentos contidos no trabalho de cuidado não são nenhum mistério para quem tem alguma experiência - "mas esse conhecimento trivial se apaga diante da ideologia tenaz sobre a meiguice natural das mulheres" (Molinier, 2004b, p. 228).

Esta flutuação e ambivalência de sentimentos são reveladas em alguns momentos da pesquisa. Grande parte das participantes, ao ser questionada sobre as consequências boas e ruins do isolamento social para a maternidade, citou como implicações positivas a 'maior proximidade dos filhos' e a 'possibilidade de acompanhar de perto seu desenvolvimento'. Esta proximidade, no entanto, também é geradora de sentimentos 
ambivalentes, conforme ressalta Helen, advogada que reside em Belo Horizonte (MG) com o marido e o filho, que tem entre 1 e 2 anos de idade : "Passar mais tempo em casa é bom, posso cuidar das coisas com calma, mas a realidade é que tem sido horrivel e eu só quero que a escola volte logo pra eu ter dez minutos de paz".

Os contraintes temporais contidos no trabalho doméstico - sem horários ou ritmos fixos - pressupõem uma disponibilidade permanente das mulheres à casa e àqueles que moram nela, como desabafou Virgínia, bióloga que mora em Joinville (SC) com o marido e os dois filhos (com idades entre 6 e 8 anos) : "Preciso de tempo para mim e não tenho dez minutos sem ouvir uma mãe. Estou pirando". Tais contraintes são comumente ocultados porque costumam ser confundidos com o amor materno e conjugal - uma visão estereotipada do cuidado, que não apenas se nutre da ideologia da ternura feminina, como contribui para reforçá-la (Molinier, 2004b). Por combinar uma série de tarefas imateriais, realizadas na esfera privada e que mobilizam saberes historicamente atribuídos à natureza feminina e ao amor, o trabalho de cuidado é pouco visível e suas atividades, com frequência, só são percebidas quando não feitas ou quando malfeitas. A despeito de toda a luta feminista, o trabalho doméstico comumente não é considerado um trabalho, salvo quando atrelado à relação assalariada - e mesmo aí a sua desvalorização é evidente, tendo em vista os baixos salários pagos a empregadas domésticas e babás.

74 A falta de visibilidade do trabalho doméstico é ressaltada por Miriam: "O pior é a frustração de que nosso trabalho é invisível em relação aos trabalhos que pagam boletos". O não reconhecimento é questionado por Tamara, vendedora de doces autônoma, que mora no Rio de Janeiro (RJ) com o marido e os dois filhos, que têm entre 1 e 5 anos. Sem qualquer ajuda nas tarefas de casa e de cuidado das crianças, ela propõe : "Gostaria que os maridos fossem obrigados a ficarem em nosso lugar por um dia apenas, porém fazendo todas as nossas atividades para nos dar mais valor".

\subsection{A carga mental}

Dentre os depoimentos registrados pela pesquisa, há ainda outra queixa recorrente, mesmo entre aquelas que se disseram satisfeitas com a divisão das tarefas da casa e dos filhos : a carga mental relativa a este trabalho é sempre, ou quase sempre, assumida por elas. A noção de carga mental foi cunhada nos anos 1970 por Haicault (2020) para dar conta de uma competência particular observada em pesquisas sobre o trabalho doméstico das mulheres: a organização gestionária do conjunto das atividades cotidianas essenciais à vida doméstica das famílias. Opondo-se à redução do trabalho doméstico a um simples fazer, o termo 'carga mental' sublinha o peso dessa gestão global das atividades, sua complexidade, seus contraintes e a pluralidade de competências cognitivas que ela mobiliza. Trata-se de uma capacidade de gestão e organização, mas também de previsão, memorização e resposta aos imprevistos ; supõe o domínio das múltiplas temporalidades das atividades de cada um e seu agenciamento nos espaços de convivência familiar. Requer, assim, empatia e disponibilidade afetiva para manter o bem-estar - inclusive psíquico - da família, a curto e médio prazos (Haicault, 2020).

76 Este trabalho permanente, exaustivo e invisível é ainda maior nos domicílios com crianças pequenas. Maya é professora em São Paulo (SP) e estava lecionando de maneira remota durante o isolamento. Ainda que estivesse dividindo com o marido o 
trabalho doméstico da casa e os cuidados do filho, que tem entre 3 e 5 anos, ela fez uma ressalva: "Por mais que a execução de tarefas seja distribuída igualmente, a parte do gerenciamento ainda é totalmente minha". Esta também é a queixa de Juliana, editora de texto que mora na mesma cidade e tem um filho com idade entre 1 e 2 anos. Na ocasião da pesquisa, ela estava dividindo as tarefas da casa com o marido e uma empregada doméstica, mas sinalizou: "Tenho que pensar no que vamos comer e no que comprar para casa. Ou seja, eu gerencio e ele só executa". Apesar de estar satisfeita com a divisão do trabalho doméstico com o companheiro, com quem tem um filho de 3 a 5 anos de idade, Serena declarou: "A carga mental ainda é das mulheres, mesmo numa relação parental feminista como a que tenho. Reconheço meus privilégios e mesmo assim me sinto exausta".

Para Haicault (2020), houve recentemente na França uma tomada de consciência desta carga mental e de suas contribuições essenciais para garantir a manutenção da vida dentro de cada unidade familiar (especialmente em tempos de confinamento). A denúncia do óbvio deslanchou a partir de 2016 e o termo passou a ser usado em linguagem corrente graças à publicação de uma história em quadrinhos da ilustradora Emma Clit $\left.{ }^{10}\right]$ que, mesmo tendo simplificado a complexidade da noção, alcançou o mérito de dar visibilidade à temática. Os quadrinhos - intitulados no Brasil 'Você poderia ter me pedido' - abordam a distribuição desigual das tarefas domésticas entre casais heterossexuais, enfatizando que, mesmo os homens que 'ajudam' ou têm a perceção de corresponsabilidade das tarefas, frequentemente só o fazem se demandados pelas mulheres, ou seja, limitam-se a executar ordens explícitas, que devem ser verbalizadas mais de uma vez e de maneira convincente. É o que ressaltam os depoimentos de Nara e Roberta. Ambas residem com seus companheiros e são mães de crianças pequenas: "Meu cônjuge [...] tem pouca proatividade. Tenho que sugerir e relembrar a realização de tarefas o tempo todo" - Nara, atriz e professora, mãe de dois filhos com idades entre 1 e 5 anos, Fortaleza (CE).

"O pai faz, mediante demanda ou sempre com o suporte da mãe. Exemplos : oferece o lanche, desde que esteja preparado. Para cumprir horários, precisa ser alertado. [...] As divisões não são justas e a carga mental de fazer cobranças para que as tarefas do outro se concluam é exaustiva" (Roberta, gestora cultural, mãe de um filho com idade entre 1 e 2 anos, Niterói).

Ao esperar que suas companheiras lhe digam o que fazer (quando e como), os homens estão, na realidade, afirmando que são elas as responsáveis pelo trabalho doméstico e recusando-se a assumir responsabilidade por parte da carga mental relativa a este trabalho. A estas mulheres cabe, assim, não apenas a maior parte da execução, mas também a gestão do trabalho de planejamento e organização do conjunto destas atividades. Não raro, muitas preferem assumir essa distribuição desigual a entrar em conflito constante com seus companheiros. É o que sinalizou Elis, assistente administrativa, que mora no Rio de Janeiro (RJ) com o marido e dois filhos, com idades entre 3 e 8 anos: "Se eu não pedir mil vezes, o meu esposo não tem a iniciativa de fazer as coisas. Muitas vezes, prefiro pegar e fazer do que me estressar mais ainda".

Joana, que tem um filho com idade entre 6 e 8 anos, é produtora audiovisual e também reside no Rio de Janeiro (RJ), explicou as consequências de assumir sozinha a carga mental do trabalho doméstico :

"Ainda que a divisão das tarefas funcione entre eu [sic] e meu companheiro, a carga mental para organização e gestão das tarefas é toda minha. Além de fazer minha parte, eu preciso 'patrulhar' o trabalho alheio o tempo todo 
(senão ele não é feito), o que causa um grande desgaste emocional para todos".

$$
\begin{aligned}
& \text { que tange à divisão sexual do trabalho (Hirata \& Kergoat, 2007), nos dedicaremos na } \\
& \text { próxima seção às brechas e rupturas que se tornaram possíveis a partir das mudanças } \\
& \text { impostas pela pandemia às famílias. }
\end{aligned}
$$

\subsection{Renormatizações nos arranjos familiares}

Ao aprofundar o significado da defasagem entre trabalho prescrito e trabalho real postulada pela Ergonomia da Atividade, a Ergologia propôs algo muito mais geral, presente em toda atividade humana: uma dimensão de protocolo, ou de normas antecedentes, de um lado; e uma dimensão de encontro, ou de renormatizações, de outro. Toda atividade humana está permeada de normas antecedentes, assim definidas porque se referem a tudo aquilo que preexiste à atividade, ou seja, tudo o que está lá antes que ela se desenrole e que visa a guiá-la, orientá-la e quase enquadrá-la: os saberes relativamente estabilizados que relevam do protocolo experimental (prescritos, objetivos, regras...) e os saberes procedentes da experiência (culturas de ofício, saberfazer, valores...) (Schwartz, 2007b). No conjunto das normas antecedentes do trabalho doméstico de cuidado da casa e dos filhos, estão incluídas as relações de gênero - uma imposição do meio, que se apresenta, no entanto, de maneira naturalizada (Brito, 2005), conforme já sinalizado.

Se a dimensão protocolar, definida pela anterioridade e pelo anonimato, é fundamental porque serve de referência para os protagonistas da atividade, ela é insuficiente para dar conta das variabilidades dos meios em que as atividades se desenrolam. Como adverte Schwartz (2007b, p. 191), "todos os tipos de infidelidades se combinam, se acumulam, se reforçam uma na outra, no conjunto de um ambiente de trabalho". Desta forma, a perspetiva ergológica chama a atenção para a necessidade de que se considere, em qualquer análise do trabalho, a capacidade dos viventes de instituir outras normas para lidar com o que lhes é imposto, ou seja, as suas tentativas de estabelecer com o meio um domínio positivo, produzindo novas normas em adequação com as condições reais da atividade. Este processo de renormatização se apresenta, inclusive, em relação às normas sociais : 'cada sujeito - seja 'individual' ou 'coletivo' - afirma-se em relação às normas que institui ou contesta. Assim, a normalização social instituída não priva a sociedade, grupo ou indivíduo de sua capacidade normativa" (Brito, Neves, Oliveira, \& Rotenberg, 2012, p. 318).

Ainda que a metodologia desta pesquisa não pretendesse apreender as renormatizações de cada uma das participantes para fazer frente às infidelidades impostas pela pandemia da COVID-19 aos seus trabalhos produtivo e reprodutivo, buscou-se estar atento não apenas para os arranjos que reproduzissem incessantemente as normas sociais de gênero, mas também para aqueles que sinalizassem para contradições, falhas e brechas nestas normas. $\mathrm{Na}$ esteira do que ensina Kergoat (2009), a análise da divisão sexual do trabalho não deve remeter a um pensamento determinista, ao contrário :

“trata-se de pensar a dialética entre invariantes e variações, pois se este raciocínio supõe trazer à tona os fenômenos da reprodução social, ele implica estudar simultaneamente os deslocamentos e rupturas daquilo bem 
como a emergência de novas configurações que tendem a questionar a existência mesma desta divisão" (p. 68).

84 Assim, ao refletir sobre a dialética entre permanências e mudanças impostas pela pandemia ao trabalho doméstico e sua divisão entre os sexos, esta pesquisa interessouse também pelos novos arranjos familiares de distribuição deste trabalho. Em alguns lares, houve melhora na distribuição das tarefas domésticas : se no período anterior à pandemia os cuidados com a casa eram igualmente distribuídos entre o casal em apenas $19 \%$ dos lares pesquisados, durante o isolamento social este percentual subiu para $30 \%$ (Tabela 3); também houve aumento no percentual de pais que se dedicavam diariamente aos cuidados dos filhos, de $39 \%$ para $47 \%$ (Tabelas 5 e 6).

Alguns depoimentos também reforçam a perceção de melhoria, ainda que gradativa, como sinalizou Helena, antropóloga e professora, residente no Rio de Janeiro (RJ) e mãe de um filho com idade entre 6 e 8 anos, que voltou a viver com o ex-marido durante o período de isolamento para dividirem o trabalho doméstico: "Ainda que me sinta um pouco sobrecarregada devido aos cuidados culinários, nossa divisão de tarefas tem melhorado com o passar das semanas". A também antropóloga Bárbara, residente em Salvador (BA) e mãe de um filho com idade entre 6 e 8 anos, relatou como ela e o companheiro estabeleceram novos arranjos de divisão das tarefas domésticas: "Desde o início foi preciso dialogar sobre isso, visibilizar certos trabalhos e tarefas e fazer acordos para ficar mais equilibrada a divisão do trabalho". Sara, economista, residente em São Paulo (SP) e mãe de um filho com idade entre 6 meses e 1 ano, sinalizou como ela e o marido geriram a carga aumentada de trabalho doméstico, umas das infidelidades impostas pela pandemia : "A quarentena e o volume de trabalho nos forçaram a dividir melhor as tarefas de cuidados com a casa e com a bebê. E hoje considero uma situação muito mais igual entre mime meu cônjuge".

Para alguns casais, as estratégias adotadas para a gestão conjunta do trabalho produtivo e reprodutivo traduziram-se em arranjos menos usuais, como relatou Cora, antropóloga e pesquisadora, residente no Rio de Janeiro (RJ) e mãe de dois filhos (com idades entre 6 meses e 1 ano e 6 e 8 anos): "Estamos fazendo turnos de trabalho $e$ revezamento com as crianças e nos dividindo em relação aos cuidados com a casa". Assim, algumas famílias, ainda que poucas, conseguiram reorganizar a distribuição das tarefas de cuidado da casa e dos filhos em um paradigma mais próximo ao da 'parceria' definido por Hirata e Kergoat (2007).

É possível que se trate de renormatizações momentâneas, motivadas por necessidades passageiras impostas pelo contexto de isolamento social e que tais arranjos sejam desfeitos, fazendo com que a maior parte do trabalho doméstico retorne para as mulheres (incluindo aí as empregadas domésticas). Essas novas configurações, no entanto, também podem se revestir de um caráter duradouro, alimentando de forma mais consistente uma prática de melhor divisão das tarefas domésticas, mesmo que, em um primeiro momento, apenas no plano individual. É preciso reconhecer, ainda assim, o avanço viabilizado pela pandemia em alguns lares, inclusive no que tange à maior visibilização deste trabalho, como sinalizou Leila, arquiteta e urbanista, moradora de Porto Alegre (RS) e mãe de um filho de até 6 meses de idade : "Meu marido, por estar mais em casa, 'percebeu' o trabalho doméstico e passou a colaborar muito mais". Nesta mesma direção, Tainá - professora no Rio de Janeiro (RJ) e mãe de um filho com idade entre $1 \mathrm{e}$ 2 anos - declarou que a melhor consequência do isolamento para a sua maternidade "foi 
o pai perceber o quanto uma mãe se sente sobrecarregada ao ficar com uma criança de menos de 2 anos. [...] Que não sobra tempo pra fazer nada. Que a parceria precisa existir".

88 Ao fazer avançar a visibilização das tarefas de cuidado - e de seus esforços, suas dificuldades concretas e seus sentimentos ambivalentes - é possível que se abra caminho para que possam ser instituídas outras normas sociais de gênero, que considerem arranjos de divisão do trabalho entre os sexos nesses termos de parceria.

\subsection{Limitações da pesquisa} o link da pesquisa para outras mães do seu círculo de convívio. Ainda que se tenha buscado uma seleção plural das primeiras participantes, a replicação do questionário foi mais efetiva em alguns subgrupos, fazendo com que a amostra se concentrasse em torno de certas características de perfil. Especialmente sensível aos vieses de amostragem, o método bola de neve não possibilitou, assim, uma maior diversidade da amostra, também dificultada em função do formato on-line do questionário, que impossibilitou a participação de mães sem acesso (ou com acesso restrito) à internet. A pesquisa atingiu de maneira restrita mães negras, de classes mais baixas e/ou de baixa escolaridade, marcadores sociais que sabidamente têm profundas implicações nas experiências de trabalho doméstico das mulheres.

\section{Algumas considerações finais}

A partir dos resultados obtidos pode-se dizer que a pesquisa logrou alcançar os seus objetivos, quais sejam : apreender as principais mudanças e permanências impostas ao trabalho doméstico não remunerado de cuidados da casa e dos filhos exercido por mulheres durante o isolamento social decorrente da pandemia da COVID-19.

De forma mais ampla, a pandemia colocou o trabalho de cuidado em evidência : lançou luz sobre a imprescindibilidade de trabalhos frequentemente invisíveis, pouco reconhecidos e mal pagos, tais como aqueles relacionados à saúde, à educação, à manutenção, à alimentação básica e aos cuidados dos outros. Nas famílias, o fardo imposto pela necessidade de dar conta da gestão imediata da carga intensificada de trabalho doméstico durante a pandemia revelou a sua essencialidade cotidiana e gratuita (Haicault, 2020).

No que diz respeito ao reconhecimento do trabalho doméstico e sua distribuição desigual entre os sexos, mesmo em meio a mudanças tão significativas impostas pelo contexto de isolamento social, o que se apresentou, por um lado, foi 'mais do mesmo' : as mulheres, em grande parte dos lares, seguiram responsáveis pela maior parcela deste trabalho, intensificado durante o período. Por outro lado, ao acentuar a sobrecarga doméstica feminina, a pandemia em alguma medida também a tornou mais evidente. Na esfera individual, possibilitou, para algumas famílias, novos arranjos de 
divisão das tarefas de cuidado, ainda que limitados a determinados lares e, muito possivelmente, circunscritos a extratos sociais específicos. Na esfera pública, foi tema de estudos e pesquisas como esta, além de manchete de reportagens da grande imprensa.

O desafio para o pós-pandemia é sustentar e aprofundar a postura crítica contrária à ocultação do trabalho doméstico, que possa contribuir para diminuir o déficit crônico de reconhecimento deste trabalho e se traduzir em práticas sociais consistentes de melhor divisão de suas tarefas entre os sexos. Para tal, é fundamental seguir apostando em pesquisas sobre a temática, com estratégias analíticas que considerem a indissociabilidade entre o trabalho profissional e o doméstico, e que estejam atentas às continuidades, circulações e transferências possíveis entre eles.

\section{BIBLIOGRAFIA}

Badinter, E. (1985). Um Amor Conquistado : o mito do amor materno. Rio de Janeiro : Nova Fronteira.

Brito, J. (2005). Trabalho e Saúde Coletiva : o ponto de vista da atividade e das relações de gênero. Ciência \& Saúde Coletiva, 10(4), 879-890. https://doi.org/10.1590/S1413-81232005000400012

Brito, J., Neves, M., Oliveira, S., \& Rotenberg, L. (2012). Saúde, subjetividade e trabalho : o enfoque clínico e de gênero. Revista Brasileira de Saúde Ocupacional, 37(126), 316-329. https://doi.org/ 10.1590/S0303-76572012000200013

Brito, L., Borges, L., Fortes, P., Gomes, A., Narciso, L., Palácios, M., ... Thome, B. (2020). Impactos Sociais da Covid-19 : uma perspectiva sensivel às desigualdades de gênero. Observatório Covid-19 Fiocruz. Disponível em https://www.arca.fiocruz.br/bitstream/icict/41375/2/ ImpactosSociais.PDF

Bruschini, M. (2006). Trabalho doméstico : inatividade econômica ou trabalho não-remunerado? Revista Brasileira de Estudos de População, 23(2), 331-353. https://doi.org/10.1590/ S0102-30982006000200009

Bruschini, M., \& Rosemberg, F. (1982). A Mulher e o Trabalho. In M. Bruschini, \& F. Rosemberg (Dirs.), Trabalhadoras do Brasil (pp. 9-22). São Paulo : Brasiliense.

Coleman, J. (1958). Relational analysis : The study of social organizations with survey methods. Human Organization, 17(4), 28-36.

Dorna, L. (2018). o maternar como um tipo singular de trabalho : encontros com mães - com formação universitária - sobre suas atividades (Tese de Doutoramento). Faculdade de Psicologia da Universidade Federal Fluminense, Niterói, Brasil.

Eurofound, \& International Labour Office (ILO) (2017). Working anytime, anywhere: The effects on the world of work. Publications Office of the European Union, Luxembourg \& International Labour Office, Geneva.

Federici, S. (2019). o ponto zero da revolução : trabalho doméstico, reprodução e luta feminista. São Paulo : Elefante. 
Fougeyrollas-Schwebel, D. (2009). Trabalho doméstico. In H. Hirata, F. Laborie, H. Le Doaré, \& D. Senotier (Dirs), Dicionário Crítico do Feminismo (pp. 256-262). São Paulo : Unesp.

Goodman, L. (1961). Snowball Sampling. The Annals of Mathematical Statistics, 32(1), 148-170.

Haicault, M. (2020). La charge mentale. Histoire d'une notion charnière (1976-2020). Disponivel em https://hal.archives-ouvertes.fr/hal-02881589

Hirata, H., \& Kergoat, D. (2007). Novas Configurações da Divisão Sexual do Trabalho. Cadernos de Pesquisa, 37(132), 595-609. https://doi.org/10.1590/S0100-15742007000300005

Human Rights Watch (2017). Esquecidas e desprotegidas. O impacto do vírus zika nas meninas e mulheres no nordeste do Brasil. Disponível em https://www.hrw.org/pt/report/ 2017/07/13/306163\#5034

Instituto Brasileiro de Geografia e Estatística (2018). Síntese de indicadores sociais : uma análise das condições de vida da população brasileira. Estudos e pesquisas. Informação demográfica e socioeconômica, 39. Rio de Janeiro : IBGE. Disponível em https://biblioteca.ibge.gov.br/ visualizacao/livros/liv101629.pdf

Instituto Brasileiro de Geografia e Estatística (2019). Agência IBGE Notícias. Disponível em https:// agenciadenoticias.ibge.gov.br/agencia-sala-de-imprensa/2013-agencia-de-noticias/releases/ 27877-em-media-mulheres-dedicam-10-4-horas-por-semana-a-mais-que-os-homens-aosafazeres-domesticos-ou-ao-cuidado-de-pessoas

Instituto Brasileiro de Geografia e Estatística (2020). Pesquisa Nacional por Amostra de Domicílios Covid-19. Disponível em https://covid19.ibge.gov.br/pnad-covid/

Instituto de Pesquisa Econômica Aplicada (2020). Potencial de teletrabalho na pandemia : um retrato no Brasil e no mundo. Disponível em https://www.ipea.gov.br/portal/images/stories/PDFs/ conjuntura/200608_nt_cc47_teletrabalho.PDF

Ipsos (2020). Women's Forum for the economy and society. https://www.ipsos.com/sites/default/ files/ct/news/documents/2020-11/womens-forum-2020.pdf

Kergoat, D. (2009). Divisão sexual do trabalho e relações sociais de sexo. In H. Hirata, F. Laborie, H. Le Doaré, \& D. Senotier (Dirs), Dicionário Crítico do Feminismo (pp. 67-75). São Paulo : Unesp.

Menéndez, C., Lucas, A., Munguambe, K., \& Langer, A. (2015). Ebola crisis : the unequal impact on women and children's health. The Lancet. https://doi.org/10.1016/S2214-109X(15)70009-4

Molinier, P. (2004a). Psicodinâmica do trabalho e relações sociais de sexo. Um itinerário interdisciplinar. 1988-2002. Produção, 14(3), 14-26. http://dx.doi.org/10.1590/ S0103-65132004000300003

Molinier, P. (2004b). O ódio e o amor, caixa preta do feminismo ? Uma crítica da ética do devotamento. Psicologia em Revista, 10(16), 227-242. https://doi.org/10.5752/P. 1678-9563.2004v10n16p227-242

Organização das Nações Unidas - ONU Mulheres (2020). Gênero e Covid-19 na América Latina e no Caribe : dimensões de gênero na resposta. Disponível em http://www.onumulheres.org.br/wpcontent/uploads/2020/03/ONU-MULHERES-COVID19_LAC.pdf

Schwartz, Y. (2007a). O homem, o mercado e a cidade. In Y. Schwartz, \& L. Durrive (Dirs.), Trabalho e Ergologia : conversas sobre a atividade humana (pp. 249-275). Niterói : EdUFF.

Schwartz, Y. (2007b). Trabalho e uso de si. In Y. Schwartz, \& L. Durrive (Dirs.), Trabalho e Ergologia : conversas sobre a atividade humana (pp. 191-224). Niterói : EdUFF. 
Sempreviva Organização Feminista, \& Gênero e Número (2020). Sem Parar : o trabalho e a vida das mulheres na pandemia. http://mulheresnapandemia.sof.org.br/wpcontent/uploads/2020/08/ Relatorio_Pesquisa_SemParar.pdf

Sorj, B., \& Fontes, A. (2012). O care como regime estratificado : implicações de gênero e classe social. In H. Hirata, \& N. Guimarães (Dirs), Cuidado e Cuidadoras : as várias faces do trabalho do care (pp. 103-116). São Paulo : Atlas.

World Health Organization (2019). Gender equity in the health workforce : analysis of 104 countries. Working paper 1. Geneva : World Health Organization.

\section{NOTAS}

1. Conforme entrevista concedida por Phumzile Mlambo-Ngcuka, diretora-executiva da ONU Mulheres. Disponível em: https://www.onumulheres.org.br/noticias/violencia-contra-asmulheres-e-meninas-e-pandemia-invisivel-afirma-diretora-executiva-da-onu-mulheres/

2. Atualmente Laboratório Gênero, Trabalho e Mobilidade (GTM).

3. A Silo - Arte e Latitude Rural é uma organização da sociedade civil que se dedica a difundir projetos que proporcionem intercâmbio transdisciplinar entre diferentes áreas, estimulando o cruzamento entre saberes intuitivos e saberes científicos.

4. Google Docs.

5. Os nomes das participantes são fictícios.

6. WhatsApp.

7. A pesquisa permitia assinalar mais de um cuidador por frequência de cuidado, de forma a refletir os diferentes arranjos familiares.

8. Conforme aponta o relatório da Organização para a Cooperação e Desenvolvimento Econômico [OCDE]. Disponível em https://www.oecd-ilibrary.org/education/education-at-aglance-2020_69096873-en

9. O termo 'contrainte', conceito usado pela Ergonomia, tem sido traduzido frequentemente por exigência. Diante da dificuldade de traduzi-lo para uma palavra equivalente, que incorpore o sentido de pressão, de constrangimento, o termo em francês foi mantido.

10. Disponível em https://emmaclit.com

\section{RESUMOS}

As mudanças e permanências no trabalho doméstico não remunerado de cuidados da casa e dos filhos durante a pandemia da COVID-19 são o objeto deste artigo. Discutem-se no texto os resultados de uma investigação realizada a partir de pesquisa on-line com 360 mães brasileiras com filhos de até 12 anos. Os resultados encontrados revelam : por um lado, a manutenção/ acentuação da distribuição desigual do trabalho reprodutivo entre os sexos em grande parte dos lares, com o aumento significativo de horas dedicadas pelas mães a estas tarefas, queixas relacionadas à sobrecarga física e mental e outras dificuldades específicas ao contexto de isolamento social ; por outro lado, para algumas famílias, o contexto propiciou novos arranjos de 
distribuição das tarefas ou, ao menos, tornou mais visível a essencialidade e a penosidade do trabalho doméstico, frequentemente desvalorizado e eufemizado.

Los cambios y la permanencia en el trabajo doméstico no remunerado de cuidar el hogar y los niños durante la pandemia de COVID-19 son el tema de este artículo. En el texto se discuten los resultados de una investigación realizada a partir de una encuesta en línea dirigida a 360 madres brasileñas con hijos hasta los 12 años. Los resultados encontrados revelan: por un lado, el mantenimiento / acentuación de la distribución desigual del trabajo reproductivo entre los sexos en la mayoría de estos hogares, con un aumento significativo de las horas dedicadas por las madres a estas tareas, quejas relacionadas con la sobrecarga física y mental y otras dificultades específicas del contexto de aislamiento social ; por otro lado, para algunas familias, este contexto proporcionó nuevos arreglos para la distribución de tareas o, por lo menos, ha hecho más visible la esencialidad y el dolor del trabajo doméstico, a menudo infravalorado y eufemizado.

Les changements et la permanence du travail domestique non rémunéré, consistant à s'occuper de la maison et des enfants, pendant la pandémie du COVID-19 sont l'objet de cet article. Les résultats d'une enquête, menée sur base d'une enquête en ligne auprès des 360 mères brésiliennes, d'enfants de moins de 12 ans, sont discutés dans l'article. Les résultats révèlent: d'une part, le maintien/renforcement d'une répartition inégale du travail reproductif entre les sexes dans la plupart de ces foyers, avec augmentation significative des heures consacrées par les mères à ces tâches, des plaintes liées à une surcharge physique et mentale, et d'autres difficultés propres au contexte d'isolement social ; d'autre part, pour certaines familles, le contexte a incité à de nouvelles modalités de répartition des tâches ou, du moins, a rendu plus visible le caractère essentiel et la pénibilité du travail domestique, souvent dévalorisés et euphémisés.

The changes and permanencies in unpaid domestic work to take care of home and children during the COVID-19 pandemic is the subject of this article. The text discusses the results of an investigation carried out based on an online survey of 360 Brazilian mothers with children up to 12 years old. The obtained results reveal : on the one hand, the maintenance / accentuation of the unequal distribution of reproductive work between the sexes in most households, with a significant increase in hours dedicated by mothers to these tasks, complaints related to physical and mental overload and other difficulties specific to the context of social isolation; on the other hand, for some families, the context provided new arrangements for the distribution of tasks or, at least, has made the essentiality and pain of domestic work, which is often undervalued and euphemized, more visible.

\section{ÍNDICE}

Palabras claves: trabajo doméstico, trabajo de cuidados, división sexual del trabajo, género, pandemia

Palavras-chave: trabalho doméstico, trabalho de cuidado, divisão sexual do trabalho, gênero, pandemia

Mots-clés: travail domestique, travail de soin, division sexuelle du travail, genre, pandémie

Keywords: domestic work, caring labor, sexual division of work, gender, pandemic 


\section{AUTOR}

\section{LIVIA BORGES HOFFMANN DORNA}

https://orcid.org/0000-0002-3188-8538

Grupo de Pesquisas Gestão, Trabalho e Atividade (GESTA) - Universidade Federal Fluminense, Rua Professor Manoel Ferreira, 127/ 405 - Gávea, Rio de Janeiro

liviahoffmann@gmail.com 